\title{
Editorial: Ecosystem Approach to Fisheries in the Mediterranean and Black Seas - Advances in Research and Technologies
}

\author{
Violin Stoyanov Raykov ${ }^{1 *+}$, Petya Pavlova Ivanova ${ }^{1+}$, Cemal Turan ${ }^{2 \dagger}$ and Ertug Duzgunes ${ }^{3+}$ \\ ${ }^{1}$ Department of Marine Biology and Ecology, Institute of Oceanology, Bulgarian Academy of Sciences, Varna, Bulgaria, \\ ${ }^{2}$ Fisheries Genetics and Molecular Ecology Laboratory, Marine Science Department, Marine Sciences and Technology \\ Faculty, Iskenderun Technical University, Iskenderun, Turkey, ${ }^{3}$ Faculty of Marine Science, Karadeniz Technical University, \\ Trabzon, Turkey
}

Keywords: management, models, genetic tools, measures, indicators, Black Sea, Mediterranean

\section{Editorial on the Research Topic}

Ecosystem Approach to Fisheries in the Mediterranean and Black Seas - Advances in Research and Technologies

\section{INTRODUCTION}

\section{OPEN ACCESS}

Edited and reviewed by: Maria Lourdes D. Palomares, University of British Columbia, Canada

*Correspondence: Violin Stoyanov Raykov vio_raykov@abv.bg

${ }^{\dagger}$ These authors have contributed equally to this work

Specialty section:

This article was submitted to Marine Fisheries, Aquaculture and

Living Resources,

a section of the journal

Frontiers in Marine Science

Received: 31 January 2020

Accepted: 22 June 2020

Published: 28 July 2020

Citation:

Raykov VS, Ivanova PP, Turan C and Duzgunes E (2020) Editorial: Ecosystem Approach to Fisheries in the Mediterranean and Black Seas Advances in Research and Technologies. Front. Mar. Sci. 7:577.

doi: 10.3389/fmars.2020.00577
The ecosystem approach for fisheries management is a widely accepted concept and has recently been developed to address the failures of traditional fisheries management practices (Morishita, 2008). Various international instruments require its application, improving on single-species fisheries. There is an increasing realization of the importance of species-to-species interactions, genetic tools for fishery stock structure determination, and defining stock boundaries to underpin sustainable fishery management. Thus, ecosystem models play strategic roles by providing an ecosystem context for single-species management decisions. Moreover, tactical ecosystem models can respond dynamically to any ecological and environmental variations. For example, to respond to the lack of comprehensive information about fishing activity catch quantities and composition, and how they affect the current state of Black Sea fish stocks (Raykov and Bikarska, 2011).

The studies included in this Research Topic provide novel sources of information for Mediterranean and Black Sea fisheries, spanning from mass-balance models to new fishing technologies that reduce bycatch of non-target species.

The Ecopath mass-balance model of the central Aegean Sea developed by Dimarchopoulou et al. provides a better understanding of the structure and functioning of a protected ecosystem and the ecological role of the main species of interest. This and results from Russo et al. show that the combined effects of traditional fishing effort regulation with spatial/temporal closures are important in the management action plans toward a reduction of ecosystem exploitation. The study of Darmanin and Vella describes recreational fishing in the Mediterranean as marginal with no impacts on the marine ecosystem. Fishing gears, with all their intrinsic variability, represent the physical link between a fishing management strategy and the target populations directly affected by its application (Sala et al.).

The mean size of the landed catch can be applied as a key ecosystem-based indicator, notably in monitoring exploited marine communities. The evolution of this indicate over time demonstrates long-term exploitation impacts on fishing communities and can help indicate when fishing may be closed as shown in Vasapollo et al.. Genetic structure of species is crucial for effective management of environmental resources, and genetic population data analyses have been proposed as a new 
indicator of biological monitoring. This is demonstrated in Paterno et al. using a genome-wide approach to the phylogeography of the mussel (Mytilus galloprovincialis) in the Adriatic and Black Seas. Such studies show the impact of fisheries on genetic diversity and the structure of exploited populations and inform strategies for long-term management and conservation of fisheries resources Turan et al..

Finally, the incidental capture of non-target species is one of the major threats to marine megafauna. Current knowledge on sea turtles-fishing gear interaction and mitigation measures implementation is insufficient to hinder the decline of turtle populations in the Mediterranean. Lucchetti et al. demonstrated this for the sea turtle in the Mediterranean, where incidental catches pose the main threat to its conservation. Furthermore,

\section{REFERENCES}

Morishita, J. (2008). What is the ecosystem approach for fisheries management? Mar. Policy 32, 19-26. doi: 10.1016/j.marpol.2007. 04.004

Raykov, V. S., and Bikarska, I. (2011). "Marine living resource management and fishing effort control because given socio-economic reality: alternatives and measures," in Agricultural and Environmental Informatics, Governance and Management: Emerging Research Applications (IGI Global), 299-317.
Pulcinella et al. argued for the introduction of bycatch reducer devices in different Mediterranean fisheries. These two studies are among the first to evaluate incidental capture of loggerhead turtles in a Mediterranean sub-basin fishing métier.

\section{AUTHOR CONTRIBUTIONS}

All authors listed have made a substantial, direct and intellectual contribution to the work, and approved it for publication.

\section{ACKNOWLEDGMENTS}

We thank all authors and reviewers for their valuable contributions.

Conflict of Interest: The authors declare that the research was conducted in the absence of any commercial or financial relationships that could be construed as a potential conflict of interest.

Copyright (C) 2020 Raykov, Ivanova, Turan and Duzgunes. This is an open-access article distributed under the terms of the Creative Commons Attribution License (CC $B Y)$. The use, distribution or reproduction in other forums is permitted, provided the original author(s) and the copyright owner(s) are credited and that the original publication in this journal is cited, in accordance with accepted academic practice. No use, distribution or reproduction is permitted which does not comply with these terms. 